\title{
LA PLATA RADIOCARBON LABORATORY LIQUID SCINTILLATION COUNTING AND INTER-LABORATORY CHECK SAMPLES
}

\author{
ROBERTO ANDRES HUARTE and ANIBAL JUAN FIGINI \\ Laboratorio de Tritio y Radiocarbono, LATYR, Facultad de Ciencias \\ Naturales y Museo, Paseo del Bosque, 1900 La Plata, Argentina
}

\section{INTRODUCTION}

The development and improvement of benzene synthesis for radiocarbon dating by liquid scintillation counting was started at LATYR in 1981 . The basic technique employed was described by Polach, Gower \& Frazer (1972). The line of benzene synthesis is similar to that used by Coleman et al (1972). The pretreatment of the samples and transformation to $\mathrm{CO}_{2}$ has been previously described (Figini $e t a l, 1984$ ). The conditions of measurement were partially determined according to Pearson (1979). Results of measurements of interlaboratory check samples using the technique described are given.

\section{MATERIAL AND METHODS}

\section{Benzene Synthesis}

The conversion of 0.26 moles of $\mathrm{CO}_{2}$ to $\mathrm{Li}_{2} \mathrm{C}_{2}$ is carried out in a stainless steel reactor in which are placed $20 \mathrm{~g}$ of lithium metal shot, low sodium grade (produced by Lithium Corp of America), maintained in ether of petroleum anhydrous. This quantity is $100 \%$ in excess of the stoichiometric amount needed. After the reactor is closed and evacuated, the reaction is carried out by heating to $650^{\circ} \mathrm{C}$ in a furnace, maintaining a pressure of $\mathrm{CO}_{2}$ to be absorbed into molten lithium at $56 \mathrm{~cm} \mathrm{Hg}$ for $20 \mathrm{~min}$. In order to assure the total transformation at $\mathrm{Li}_{2} \mathrm{C}_{2}$, the reactor is heated to $1000^{\circ} \mathrm{C}$ for $30 \mathrm{~min}$. Any extraneous gases are removed with a vacuum pump. When the reactor reaches room temperature, the lower part is cooled by dipping in a bath at $0^{\circ} \mathrm{C}$. Under these conditions the hydrolysis of lithium carbide is performed by slowly adding (one hour) of $1.5 \mathrm{~L}$ of distilled water. When normal yields of $\mathrm{CO}_{2}$ to $\mathrm{C}_{2} \mathrm{H}_{2}$ are obtained (98 to $100 \%$ ) the alkaline solution is clear. Occasionally, when yields were low, the solution turned black, with a few carbonaceous particles and encrustations at the bottom of the reactor. This clearly demonstrated that the predominant reaction had been the transformation in $\mathrm{C}$ and $\mathrm{Li}_{2} \mathrm{O}$. In some cases, the solution was whitish, indicating the formation of $\mathrm{Li}_{2} \mathrm{CO}_{3}$ by a secondary reaction (Belluomini $e$ t al, 1978) and with a strong $\mathrm{NH}_{3}$ odor. This implies that air was introduced into the system through a leak in the vacuum (Griffin \& Druffel, 1985).

The following vanadium catalyzers (Harshaw Chemical Co) were tested for the trimerization of $\mathrm{C}_{2} \mathrm{H}_{2}$ to $\mathrm{C}_{6} \mathrm{H}_{6}$, according to Coleman et al (1972): V-0301, T1/8; V-0501, T1/8; V-0601, T1/8. Also used as catalyzer support of cracking HFZ, Houdei $310 \mathrm{~m}^{2}$ according to Noakes, Kim \& Akers (1967). In all these cases, benzene production was negligible. When we used 
V-0701, T1/8 (Harshaw Chemical Co), the first trials rendered unequal yields. The best results were obtained by leaving the catalyzer $(40 \mathrm{~g})$ in the oven at $550^{\circ} \mathrm{C}$ for more than $48 \mathrm{hr}$ and transferring it while hot to the catalyst column, evacuating up to $10^{-3}$ torr. Following this procedure, the catalyzer was re-used effectively for more than 30 syntheses, with no evidence of memory effect. Trimerization was carried out at $0^{\circ} \mathrm{C}$, maintaining a pressure of $\mathrm{C}_{2} \mathrm{H}_{2}$ of $76 \pm 10 \mathrm{~cm} \mathrm{Hg}$ on the catalyzer. Thirty minutes were sufficient for a reaction of 0.13 moles of $\mathrm{C}_{2} \mathrm{H}_{2}$. The last trace of $\mathrm{C}_{2} \mathrm{H}_{2}$ was frozen into the column by submerging its end into liquid $\mathrm{N}_{2}$. The column was then isolated and left standing at room temperature overnight. The recovery of benzene was carried out by heating the catalyst column in a furnace, under vacuum, at $125^{\circ} \mathrm{C}$ for $2 \mathrm{hr}$. Chemical conversion yields for the $\mathrm{CO}_{2}$ to $\mathrm{C}_{6} \mathrm{H}_{6}$ is $\bar{\Sigma} 85 \%$.

\section{Measurement}

Analysis of the final benzene samples for radiocarbon activity was performed in a Beckman LS-100 liquid scintillation spectrometer, using commercial Packard vials $(20 \mathrm{ml})$ of low potassium glass. Thirty vials were selected for their similarity of weight (Harkness \& Wilson, 1972). In order to minimize evaporative loss through the standard vial seal, new seals were made with viton O-rings, a specially fitted PTFE stopper and a plastic screw cap. The glass vial was masked with black paint on white above the level reached by the top of the scintillation liquid so as to reduce cross-talk between counter photomultiplier tubes (Pearson, 1979).

A fraction (2ml) of the benzene sample was weighed (1.758g) out accurately into the counting vial. To this was added $0.5 \mathrm{ml}$ of a scintillation solution, composed of PPO and POPOP in scintillation grade toluene, with final concentrations in the vial of $5 \mathrm{~g} / \mathrm{L}$ and $0.05 \mathrm{~g} / \mathrm{L}$, respectively. The medium value of the background $(5.4 \mathrm{cpm})$ and standard $(13.5 \mathrm{cpm})$ was individually determined for each of the vials. No memory effect was noticed during the alternate measurement of background and standard. The measurement was made at intervals of $100 \mathrm{~min}$, alternating background, sample, and standard. The energy window for the measurement of ${ }^{14} \mathrm{C}$ was adjusted placing the lowest limit at the end of the ${ }^{3} \mathrm{H}$ curve. The net counts were corrected for loss of weight and normalized to $1.758 \mathrm{~g}$. Benzene background was synthesized from acidification of $\mathrm{CaCO}_{3}$ USP light (powder) TAC Mallinckrodt Art 4052. Benzene Merck Art 1783 was used for routine measurements. Standard benzene was synthesized from wet oxidation of the NBS oxalic acid (SRM 4990B), following the method of Valastro, Land and Varela (1977). For routine measurements, we used a standard prepared by dilution of benzene marked ${ }^{14} \mathrm{C}$ (supplied by Lab de Metrologie des Rayonnements Ionisants, Gif-Sur-Yvette, with an activity of $1.042 \times$ $10^{-6} \mathrm{Ci} / \mathrm{g}$ ), up to an activity equal to the standard of reference NBS oxalic acid. Date calculations were previously given (Figini et al, 1984). $\mathrm{No}^{13} \mathrm{C} /{ }^{12} \mathrm{C}$ ratios were measured and results are not corrected for ${ }^{13} \mathrm{C}$ fractionation. ters.

Sample descriptions are based on information provided by submit- 
INTER-LABORATORY CHECK SAMPLES

Norway

LP-72a.

$9340 \pm 210$

Shells (Mya truncata) subm by Otto Salvigsen, Norsk Polarinst, dated at $9480 \pm 140$ (T-2919, OS, pers commun). Comment: another portion of the same sample was determined by gas counting at $9280 \pm 250$ (LP-72: R, 1984, v 26, no. 1, p 128).

\section{New Zealand}

LP-73a. Hollyford Valley

$7890 \pm 110$

Shells (Amphiderma $s p$ ) from lower Holly Ford valley, SW corner, S Island, New Zealand. Subm by H S Jansen, Inst Nuclear Sci, DSIR, New Zealand, dated at $7670 \pm 70$ (R-9048, internal no. New Zealand lab, HSJ, pers commun). Comment: another portion of same sample was determined by gas counting at $7460 \pm 210(\mathrm{LP}-73: \mathrm{R}, 1984$, v 26, no. 1, p 128).

\section{France}

LP-83. Le Grau du Roi 25644, Le Petit Travers, Hérault $7250 \pm 100$

Shells from oldest offshore bar, between Mangio pond and sea, at Le Grand Travers $\left(43^{\circ} 44^{\prime} \mathrm{N}, 4^{\circ} 03^{\prime} \mathrm{E}\right)$. Subm by J Evin, CDAI, Lyon. Age reported was $7050 \pm 100(\mathrm{Ly}-1511: \mathrm{R}, 1979$, v 21, no. 3, p 426).

\section{Sweden}

\section{LP-101. Southern Baltic 4}

$9650 \pm 90$

Wood from large pine stump coll at $52 \mathrm{~m}$ depth $\left(55^{\circ} 43^{\prime} \mathrm{N}, 14^{\circ} 28^{\prime} \mathrm{E}\right)$. Subm by S Håkansson, Lund. Age given was $9420 \pm 95$ (Lu-890: R, 1976, v 18, no. 3, p 293).

\section{LP-103. Kasi Mysuseter}

$4500 \pm 100$

Wood (Pinus $s p$ ) id by $\mathrm{T}$ Bartholin from bottom of unintentionally drained small lake near Kasi Mt, ca $1 \mathrm{~km} \mathrm{~N}$ of Mysuseter $\left(61^{\circ} 49^{\prime} \mathrm{N}, 9^{\circ} 40^{\prime}\right.$ E). Alt ca $1000 \mathrm{~m}$. Subm by $\mathrm{S}$ Håkansson. Age reported was $4890 \pm 65$ (Lu995, SH, pers commun). Comment: both samples were pretreated in same manner as Lund lab (SH, pers commun).

\section{United States}

\section{LP-134. Wisconsin}

$11,920 \pm 140$

Wood from Two Creeks interstadial, on $\mathrm{W}$ shore of Lake Michigan $\left(44^{\circ} 19^{\prime} 40^{\prime \prime} \mathrm{N}, 87^{\circ} 32^{\prime} \mathrm{W}\right)$. Subm by A Long, Univ Arizona. Several dates between 11,700 to 12,200 BP (AL, pers commun). 


\section{CONCLUSIONS}

The methodology we employed to obtain benzene is efficient and produces a radiochemically pure product. The operative form of the vanadium catalyzer (V-0701, T1/8) produces good results with higher yields of benzene when longer in the oven at $550^{\circ} \mathrm{C}$. The catalyzer prepared by LATYR did not produce the desired results, probably due to the catalyzer support employed. The ${ }^{14} \mathrm{C}$ results of the inter-laboratory check samples agree with those determined by other laboratories.

\section{ACKNOWLEDGMENTS}

The authors wish to express their thanks to the Consejo Nacional de Investigaciones Científicas y Técnicas, CONICET, of Argentina for their support. They are very thankful to $\mathrm{O}$ Salvigsen, H S Jansen, J Evin, S Håkanson, and A Long for their provision of inter-laboratory check samples. Their special gratitude to the Facultad de Ciencias Naturales y Museo, Universidad Nacional de La Plata, Argentina and to the Centro de Estudios Parasitológicos y de Vectores, CEPAVE, also, to J E Carbonari for his collaboration.

\section{REFERENCES}

Belluomini, G, Delfino, A, Manfra, L, and Petrone, V, 1978, Benzene synthesis for radiocarbon dating and study of the catalyst used for acetylene trimerization: Internatl Jour Applied Radiation Isotopes, v 29, p 453-459.

Coleman, D, Liu, C L, Dickerson, D R, and Frost R R, 1972, Improvement in trimerization of acetylene to benzene for radiocarbon dating with a commercially available vanadium oxide catalyst, in Rafter, $\mathrm{T}$ A and Grant-Taylor, $\mathrm{T}$, eds, Internatl conf on radiocarbon dating, 8th, Proc: Wellington, New Zealand, v 1, p B50-51

Figini, A, Gomez, G, Carbonari, J, Huarte, R and Zubiaga, A, 1984, Museo de La Plata radiocarbon measurements I: Radiocarbon, v 26, no. 1, p 127-134.

Griffin, S and Druffel, E, 1985, Woods Holes Oceanographic Institution Radiocarbon Laboratory: sample treatment and gas preparation: Radiocarbon, v 27, no. 1, p 43-51.

Harkness, D D, and Wilson, H W, 1972, Some applications in radiocarbon measurement at the Scottish Research Reactor Centre, in Rafter, T A and Grant-Taylor, T, eds, Internatl conf on radiocarbon dating, 8th, Proc: Wellington, New Zealand, v 1, p B101-B105.

Noakes, J, Kim, S and Akers, L, 1967, Recent improvements in benzene chemistry for radiocarbon dating: Geochim et Cosmochim Acta, v 31, p 1094-1096.

Pearson, G W, 1979, Precise ${ }^{14} \mathrm{C}$ measurement by liquid scintillation counting: Radiocarbon, $v$ 21, no. 1, p $1-21$.

Polach, H, Gower, J and Fraser, I, 1972, Synthesis of high purity benzene for radiocarbon dating by the liquid scintillation method, in Rafter, T A, and Grant-Taylor, T, eds, Internatl conf on radiocarbon dating, 8th, Proc: Wellington, New Zealand, v 1, p 145-157.

Valastro, S, Land, L S and Varela, A G, 1977, An improved procedure for wet oxidation of the ${ }^{14} \mathrm{C}$ NBS oxalic acid standard: Radiocarbon, v 19, no. 3, p 375-382. 